\title{
The Effect of Religious Commitment on Psychological Security: The Case of Female Students at Irbid University College
}

\author{
Dr. Naser Ibrahim Alsharah ${ }^{1}$, Dr. Abd-Alnaser Ahmad Alazam², Dr. Nayef Fadous Alhamad ${ }^{3}$ \& Faisal Khlaif \\ Al-Sharaah ${ }^{4}$ \\ ${ }^{1}$ Associate Professor in foundation of Education, Al- Balqa Applied University, salt, Jordan \\ ${ }^{2}$ Assistant Professor in Educational Psychology, Al- Balqa Applied University, salt, Jordan \\ ${ }^{3}$ Associate Professor of Psychological Counselling, Al- Balqa Applied University, salt, Jordan \\ ${ }^{4}$ Assistant Professor in Special Education, Al- Balqa Applied University, Jordan
}

Correspondence: Naser Ibrahim Alsharah, Associate Professor in foundation of Education, Al-Balqa Applied University, salt, Jordan

Received: September 10, 2018 Accepted: October 8, 2018 Online Published: October 18, 2018

doi:10.5539/res.v10n4p124

URL: https://doi.org/10.5539/res.v10n4p124

\begin{abstract}
Both a 75-items and a 30-items scales were used to uncover the relationship between religious commitment and psychological security among a sample of (156) female students in Irbid University College. Answers revealed that female students are religiously committed as they are psychologically secure. The study has found out that academic average, and income influence the degree of religious commitment of sample, but not their psychological security. Meanwhile, the study proved that parents' religiosity and relationship influence their daughters' religious commitment and psychological security. In this retrospect, the study suggests to conduct further research that tackle the behavioural (treatment) aspect of religion on students, and father-child relationship, and psychological security.
\end{abstract}

Keywords: religious commitment, psychological security, Irbid university college, female students

\section{Introduction}

A sense of security is one key element that every human being needs survive. Since the first concern is self-protection, it started to refer to security as one of the human attempts to feel safe against any threats in the surrounding environment. From this, the concept of living and socialising has emerged within groups and created bonds of mutual protection. There are many reasons that cause fear, anxiety, and stress that accompany human beings since they born, until the moment, they die. However, human beings try hard to grant safety and rejoice happiness; it is the ultimate desire sought in a time where challenges, problems and changes - cultural, social and economic- are increasing in a form that produces heavy burden. Without spiritualties that override human's thoughts, security and life goals would not be achievable as problems to be overcome (Adebayo \& Mansikka, 2018).

Psychological security is not easy to be obtained, as scientists have theorised that the survival is associated with the way of responding to potential threats (Madrigal, 2018), while human beings try to overcome and defeat these potential threats by finding ways that bring happiness by helping others and performing actions of charity. In this context, Zwoliński (2016) argues that such a sense of happiness and comfort cannot be achieved unless a spiritual relationship with God the Almighty is established to face life's challenges.

According to Krause et al. (2018), religious involvement and happiness are quite connected positively in different ways; worship services provide emotional support that affects the level of satisfaction and well-being. In other words, the more people practice religion and worship services, the more they tend to be compassionate and happy about their life. Religious commitment forms a source of happiness; it reflects positively on actions and behaviours as it makes humans happy and safe (Edling et al., 2014).

Golmakani et al. (2018) found out that spirituality aspects bring the feeling of happiness up, as well as religious activities that greatly influence human beings who are in a healthy state of mind. Many verses in the Holy Quran show a strong relationship between religious commitment and psychological security, which indicates that there is a great assurance of the importance of security in humans' life to face fear, hunger, and any other sources of danger that 
threaten their lives or communities.

Psychological security is considered one of the complicated concepts in psychology, since it is linked and influenced by several other concepts including happiness, comfort, and self-security. Researchers have described it as individual's feeling to be loved and accepted by others and the fulfilment of the need of being in an enthusiastic social environment where the feeling of being threatened and anxious is no longer there (Kelly et al. 2008; Eisenstein \& Clark, 2014). Psychological security is the main element that indicates the state of well-being. It's a dynamic process that reflects on the way people deal with danger and actual threats until well-being emerges (Zotova \& Karapetyan, 2018).

Bordovskaia \& Baeva (2015) have showed that the feelings of happiness, comfort, and protection against diseases and pain are the main indicators for achieving psychological security. It is also correlated with the emotional comfort that is represented by the ability to satisfy the needs of being unthreatened that is caused by a person's instinct for survival (Francis \& Robbins, 2017). Eisenstein \& Clark (2018) argue that religious beliefs have a connection to create a state of psychological security, as these beliefs influence the values and the behaviours that improve the feeling of being secure and develop psychological security traits.

Psychological security is one of the basic needs that human beings seek. If the world around them is not reassuring, they will be full of fear and threat. Psychological insecurity leads to the emergence of personal and emotional disorders. In Jordan, Many suicide attempts have been registered within the last 10 years. The Directorate of Public Security (Al-Rai Newspaper, 2017) indicated that unsuccessful suicide attempts amounted to (338) cases in the first nine months of 2017, the most of which were females; the reports also indicated that most of them had feelings and problems regarding personality, mental health issues, and emotional imbalance.

The study investigates the relationship between religious commitment and psychological security among a sample of female students at Irbid University College in Jordan. Moreover, it seeks to bring insights and evidence that support the future research as it attempts to answer the following questions:

1) What is the level of religious commitment among Irbid University College female students?

2) Are there significant differences at the level of significance $(\alpha=0.05)$ for the level of religious commitment among Irbid University College female students due to academic average, parents' religious commitment, family income, and Relationship among Parents?

3) What is the level of psychological security among Irbid University College female students?

4) Are there significant differences at the level of significance $(\alpha=0.05)$ for the level of psychological security among Irbid University College female students due to academic average, parents' religious commitment, family income, and Relationship among Parents?

5) Is there a statistically significant relationship between the level of religious commitment and the level of psychological security among Irbid University College female students?

\subsection{Religious Commitment}

Religion has long been recognised as a central source of meaning in life, providing individuals with core beliefs, expectations, and goals, as well as placing the individual's life into a larger, more ultimate context, and protects communities from violent crimes (Pope et al., 2018). A variety of psychological well-being aspects have been shown to be associated with religiosity, including the meaning of life. Religious conversion has been shown to relate to enhancement in the meaning in life (Wagani \& Colucci, 2018). Religious faith has a strong correlation with the experience of the meaning in life and well-being more broadly; Religion serves as a way that provide meaning for people's lives through which they can comprehend their experiences and the reason of their existence, in other words, it contributes to people's beliefs regarding themselves and the world around them (Steger et al., 2010).

Agorastos et al. (2014) have defined religious commitment as a personal feature that occurs due to mental orientations (cognitive ones) that affects the daily life through performing different rituals. It is also defined as the person's commitment toward a particular faith by applying its values in practice and performing prayers (Sayeed \& Prakash, 2013). The religious commitment in Islam has a different concept; it refers to the real commitment in behaviour that also includes any mental, psychological, or physical activity individuals do base on Islam teachings (Sabry \& Vohra, 2013). Accordingly, religious commitment can be defined as 'the heart's acknowledgement and the mind's satisfaction of everything characterised by the ethics and teachings of religion.

Religious commitment is a psychological need and innate desire inherent in the human beings; It is also a social phenomenon related to past times, where different religions emerged, having different beliefs and worship rituals (Behere et al., 2013), ranging from the Greek religion which had numerous godly figures and involved numerous ritual customs and practices that allowed the Greeks to sustain the goodwill of their gods, which came to full development in 
700s B.C. (Shean, 2016), to Christians, whom concept of God revolves around the ways in which the Divine is experienced, that being the Father, the Son (Jesus Christ), and the Holy Spirit, all which are known as the Trinity about 2000 years ago, and Muslims, who believed in Allah which they were taught about by many Prophets, Starting with the first human to set foot on earth, Adam, and ending with Prophet Muhammad (peace be upon him) (Kurtz, 2015). One of the most important components of psychological health is finding meaning in life; religion is a robust source of meaning as Abeyta \& Routledge (2018) state, as well, it is positively associated with social belonging and acceptance. The historians of religion mentioned that there is no existence for any human groups that live on earth without taking an imagined power as a God to be responsible for creation and death (Bu'ud \& Taleb, 2016). This fact gets along with the definition suggested by Gumo et al. (2012); it is referred to it as the overall belief of individuals and groups that indicates a greater power controls the universe and human connection to this power. In this context, religion is seen as a source of stability, as it can prevent humans from being anxious. Not to mention that social acceptance of a particular religion can limit the sense of commitment towards that religion, which was the first initiator to rebel against the institution of Psychiatry and the first step to criticise the thesis of neurotic religion (Ghamari, 2014).

From a Jewish perspective, Litwin et al. (2017) pointed out that there is a positive relation between the religion especially Judaism - and mental health, the finding showed that religion has a strong correlation with positive feelings, happiness, confidence, and social support. On the other hand, findings have also shown that religion has an adverse relationship with negative feelings and emotions, such as depression and abuse (Koenig, 2018). Ten Kate et al. (2017) have indicated that it is probable that being religious can offer a sense of security and safety as well as other feelings of comfort that is very much required in a human's life, emphasising that religion is an extremely important aspect that contributes to life satisfaction overall. This is supported by Miner et al. (2014), who assume that reassuring and comforting presence of God is present in the world among Christians and Muslims alike, especially with those who are deprived and sorrowful, which are explicitly present in both the Bible (e.g., Matthew 25:37-38) and the Holy Quran, which gives evidence of the closeness of Allah to those who believe in Him and no one else, providing them with a sense of security and great intimacy. In addition, Christians stress that the true, comforting presence of God can be found in humans, while Muslims believe that the projection of Allah and His presence is symbolically within the heart of believers (Lehmann \& Leighton, 2018).

\subsection{Psychological Security}

During the second half of the twentieth century, researchers and scientists concern increased regarding the concept of psychological security. Being secure, is one of main needs human tries to fulfil. It is also argued that the more the person is psychologically secured, the more the life is balanced and invulnerable with psychological and social compatibility (Afolabi \& Balogun, 2017). There are many theories that had dealt with this concept; on one hand, Freud, who proposed the Attachment theory, that tries to explicate the psychological source of a person's concept of God and its relation to psychological security. This theory suggests that there is a powerful, affectionate bond that develops between a person during his infancy and their caretakers, who're usually the parents (Bretherton, 1992; Shaver, 2017; Fonagy, 2018; Woodward, 2018). He compared this primary bond, which sole purpose is to maintain the security and safety of the child to the relationship between God and the person, as God ensures the security and safety to people who are religiously committed (Reinert \& Edwards, 2014). On the other hand, the notion of psychological security also rises from Maslow's 'Hierarchy of Needs' theory, where he had reasoned that if the security need (which is categorised as a lower-level need) is not met, the person might build up feelings of harm or danger, anxiety and tension, making them less happy about life, and might not long for the other higher-level needs anymore (Maslow \& Lewis, 1987). Psychological security is a condition, in which an individual see whether their surroundings are safe and free from harm and danger (McLeod, 2007; Afolabi \& Balogun, 2017; Stoyanov, 2017; Fallatah et al., 2018).

While from a general educational perspective, there is a theory called the 'Conservation of Resources' theory, which suggests that people devote their particular resources (e.g., self-efficacy, Emotional Intelligence) in order to handle and guard themselves against negative emotions, such as stress, difficulties of life, undermining circumstances, etc.). However, stress or deleterious life aftermaths may arise when these particular resources are being endangered, absent, or cannot be renewed after several attempts or speculations (Afolabi \& Balogun, 2017). Adler also reported that psychological security is connected with the human's ability to adapt and be happy; as such a feeling is desired by every human being. In addition, Human personality is motivated by the desire for self-actualisation and advancement (Gazi \& Shemal, 2017). These needs are produced mainly due to the fear of aggression, which leads individuals to make up for himself in a positive way. Consequently, he will feel safe. Tekke et al. (2016) concluded in their study that higher levels of personal happiness are associated with religious commitment, in which as the study found, religion, in general, envisages a positive connection with mental health, attain purpose in life and in particular with wellbeing and happiness. Another study that supports this is the point is the one made by Rizvi \& Hossain (2017), in which investigated religiosity and the state of security and internal peace. The study has found a direct connection between and reaching a 
state of security and happiness, as well, Muslims seem to be the happiest among the participants, as they claimed their faith is the main source of their feeling of happiness, satisfaction, and comfort.

Thus, it can be stated that psychological security has derived its meaning and content from the teachings of Islamic law and belief in God and that these meanings, which are held by man, lead to a sense of security, tranquillity, and freedom from anxiety and mental disorders.

\subsection{Impact of Social and Religious Factors on Psychological Security}

Many exemplary and contemporary researchers have suggested various variables that could add to the psychological interest and value of religion. In the midst of this variety of perspectives, it can be distinguished that there is a recurring subject, which is that the key function of spirituality is to safeguard the person from psychological insecurity (Hiebler-Ragger et al. 2016); people view religion as a source of comfort to rely on when managing their psychological insecurities, especially the ones regarding anxieties that cannot be put out by other people, namely, the inevitability of death, which is addressed thoroughly in the terror management theory (Tracy et al., 2011). Terror Management Theory stems from the Darwinian principle, which states that humans are inclined to self-preservation and acting upon their instinct of survival, yet are still fully conscious that their lives can easily perish by the inevitability of death; this notion results in a chronic possibility of anxiety or "terror" that requires constant management and care (Perloff, 2016). The theory also suggests people come face to face with the fact that they are fragile creatures and can easily perish by the inevitability of death, in addition to the inability of another person (e.g. parents) to provide protection against it, which, upon realisation, would lead them to return to another higher, more supreme being as their primary source of security, namely God (Soenke et al., 2013).

These claims have been supported by numerous researchers, such as Finne et al. (2014), whose study showed that there is an expansive group of psychological and social aspects that can predict psychological insecurities and mental anxiety, the most constant one being role conflict, while the lowest was positive challenge, while Amin \& Khah's (2016) study suggested that there are many factors that affect women's sense of security, such as the social capital, social order, and religious commitment. In addition, the study of Bahramian et al. (2016) showed that religious beliefs significantly affect orphans' psychological security, while the study of the study of Carlucci et al. (2015) highlighted in its results that the main positive role of religious fundamentalism is to encourage life fulfilment and psychological security.

It is evident that religious commitment is a universal human pursuit that develop the capability to cope with negative life events, and allow humans to find security and balance in their lives; there is no doubt that religious commitment is the main basis on which all aspects of life must be built on, as the state of the link between man and God is a decisive factor in influencing a person's state of mind such as peace, joy, harmony or even tension, fear, and anxiety, either achieving psychological and social harmony or descending into an abyss of negativity.

\section{Method}

This study seeks to explore the relationship between level of religious commitment and psychological security. This research consisted of two instruments contains (75) and (30) items measuring the relationship between level of religious commitment and psychological security. The scale is being distributed by hand.

The scale contains (5) demographic variables and (105) questions represent study variables:

- Psychological Security: it is formulated into benchmarks or objectives to reach, into (75) questions:

- Religious Commitment: it is formulated into benchmarks or objectives to reach, into (3) fields with a total of (30) questions:

- $\quad$ Field of Belief with (10) questions.

- Field of Worship with (10) questions

- Field of Behaviour (Treatment) with (10) questions.

\subsection{Data Analysis and Interpretation}

To answer the questions, Statistical Package for Social Sciences (SPSS) was used in processing. the following statistical techniques and tests were used in data analysis:

1) Reliability Test: To measure the reliability, stability and consistency of used scales.

2) Frequencies and percentages to describe demographical variables.

3) Descriptive Statistical Techniques: To illustrate and the responses of sample to study fields.

4) One-Way for Independent Samples: to examine the differences in sample's answers.

5) Scheffé's Test: to check for whom the differences in post ANOVA analysis. 
6) Pearson's Test: to check the relationship between the level of religious commitment and the level of psychological security.

Respondents were asked to read each item, and select one of the choices as follow:

- Score 5: For the (strongly agree)

- Score 4: For the (agree)

- Score 3: For the (neutral)

- Score 2: For the (disagree)

- Score 1: For the (strongly disagree)

\subsection{Population and Sample}

The sample is (156) students selected randomly from the college female students who study in educational science department in Balqa Applied University/Irbid in (2017/2018). The tables below show the demographic characteristics of our sample:

Table 1. Demographic Characteristics of the Sample (Academic Average)

\begin{tabular}{c|c|c}
\hline \multirow{2}{*}{ Academic Average } & \multicolumn{2}{|c}{ Sample } \\
\cline { 2 - 3 } & Frequency & Percentage \% \\
\hline More Than 85 & 6 & $3.8 \%$ \\
\hline $\mathbf{7 0 - 8 5}$ & 92 & $59.0 \%$ \\
\hline Less than 70 & 58 & $37.2 \%$ \\
\hline Total & $\mathbf{1 5 6}$ & $\mathbf{1 0 0 . 0} \%$ \\
\hline
\end{tabular}

From the table (1) it shows that the percent of category (More than 85) from the Sample was (3.8\%) mean while it was for (70-85) (59.0\%) and it was for (less than 70) (37.2\%).

Table 2. Demographic Characteristics of the Sample (Father's Degree of Religiosity)

\begin{tabular}{c|c|c}
\hline \multirow{2}{*}{ Father's Degree of Religiosity } & \multicolumn{2}{|c}{ Sample } \\
\cline { 2 - 3 } & Frequency & Percentage \% \\
\hline Very Religious & 24 & $15.4 \%$ \\
\hline Religious & 128 & $82.0 \%$ \\
\hline Irreligious & 4 & $2.6 \%$ \\
\hline Total & $\mathbf{1 5 6}$ & $\mathbf{1 0 0 . 0} \%$ \\
\hline
\end{tabular}

From the table (2) it shows that the percent of category (Very Religious) from the Sample was (15.4\%) mean while it was for (Religious) (82.0\%), and it was for (Irreligious) (2.6\%).

Table 3. Demographic Characteristics of the Sample (Mother's Degree of Religiosity)

\begin{tabular}{c|c|c}
\hline \multirow{2}{*}{ Mother's Degree of Religiosity } & \multicolumn{2}{|c}{ Sample } \\
\cline { 2 - 3 } & Frequency & Percentage \% \\
\hline Very Religious & 45 & $28.8 \%$ \\
\hline Religious & 106 & $67.9 \%$ \\
\hline Irreligious & 5 & $3.2 \%$ \\
\hline Total & $\mathbf{1 5 6}$ & $\mathbf{1 0 0 . 0 \%}$ \\
\hline
\end{tabular}

From the table (3) it shows that the percent of category (Very Religious) from the Sample was (28.8\%) mean while it was for (Religious) (67.9\%), and it was for (Irreligious) (3.2\%). 
Table 4. Demographic Characteristics of the Sample (Relationship among Parents)

\begin{tabular}{c|c|c}
\hline \multirow{2}{*}{ Relationship among Parents } & \multicolumn{2}{|c}{ Sample } \\
\cline { 2 - 3 } Preat Mutual Understanding & Frequency & $41.1 \%$ \\
\hline Moderate Mutual Understanding & 64 & $53.8 \%$ \\
\hline Filled with Problems and Conflicts & 84 & $5.1 \%$ \\
\hline Total & 8 & $\mathbf{1 0 0 . 0 \%}$ \\
\hline
\end{tabular}

From the table (4) it shows that the percent of category (Great Mutual Understanding) from the Sample was (41.1\%) mean while it was for (Moderate Mutual Understanding) (53.1\%), and it was for (Filled with Problems and Conflicts) $(5.1 \%)$.

Table 5. Demographic Characteristics of the Sample (Income)

\begin{tabular}{c|c|c}
\hline \multirow{2}{*}{ Income } & \multicolumn{2}{|c}{ Sample } \\
\cline { 2 - 3 } & Frequency & $4.5 \%$ \\
\hline High & 7 & $25.6 \%$ \\
\hline Moderate & 40 & $69.9 \%$ \\
\hline Low & 109 & $\mathbf{1 0 0 . 0 \%}$ \\
\hline
\end{tabular}

From the table (5) it shows that the percent of category (High) from the Sample was (4.5\%) mean while it was for (Moderate) (25.6\%), and it was for (Low) (69.9\%).

\subsection{Tool Validity}

Table 6. Cronbach's Alpha for the Study Fields

\begin{tabular}{|c|c|c|}
\hline $\begin{array}{c}\text { Field } \\
\text { Number }\end{array}$ & Field & Value of $(\alpha)$ \\
\hline \multirow{3}{*}{1} & Psychological Security & \\
\hline & Psychological Security & 0.799 \\
\hline & Level of Religious Commitment & \\
\hline 1 & Field of Belief & 0.754 \\
\hline 2 & Field of Worship & 0.711 \\
\hline 3 & Field of Behaviour (Treatment) & 0.641 \\
\hline
\end{tabular}

As shown from the table above that the total Cronbach's alpha For the study fields was (0.898) While the maximum for Cronbach's alpha was Psychological Security field (0.799) and the lower was at Field of Behaviour (Treatment) (0.641), all the values above are more than (0.6) which is the minimum acceptable value, which will lead to the stability of the results for this study.

\section{Results}

To analyse the data and questions, descriptive statistics for each field is calculated, as it shown as follow:

Question (1): What is the level of religious commitment for Irbid university college female students?

Means and standard deviation were calculated from the answers that were written by respondents according to the survey fields according to the following table:

Table 7. Descriptive Statistics for Religious Commitment Field

\begin{tabular}{c|c|c|c}
\hline $\begin{array}{c}\text { Field } \\
\text { Number }\end{array}$ & Field & Mean & Std. Deviation \\
\hline F1 & Field of Belief & 3.74 & 0.54 \\
\hline F2 & Field of Worship & 3.88 & 0.52 \\
\hline F3 & Field of Behaviour (Treatment) & 3.55 & 0.57 \\
\hline \multicolumn{2}{c}{ Total } & $\mathbf{3 . 7 2}$ & $\mathbf{0 . 4 4}$ \\
\hline
\end{tabular}


As it seen from the above table that the Field of Belief achieved mean which reached (3.74) and a standard deviation (0.54), the Field of Worship achieved mean which reached (3.88) and a standard deviation (0.52), in addition the Field of Behaviour (Treatment) achieved mean which reached (3.55) and a standard deviation (0.57 and finally religious commitment as total achieved mean which reached (3.72) and a standard deviation (0.44).

Question (2): Are there significant differences at the level of significance $(\alpha=0.05)$ for the level of religious commitment among Irbid University College female students due to general secondary examination average, parents' religious commitment, family income, and Relationship among Parents?

In order to answer this question, the researcher used ANOVA analysis to know the differences of the research sample among demographic variables values and the following table shows that:

Table 8. Analysis of Variance ANOVA Values

\begin{tabular}{|c|c|c|c|c|c|c|}
\hline Dimension & $\begin{array}{c}\text { Demographic } \\
\text { Variable }\end{array}$ & $\begin{array}{l}\text { Sum of } \\
\text { Squares }\end{array}$ & $\begin{array}{l}\text { Degree of } \\
\text { Freedom }\end{array}$ & $\begin{array}{c}\text { Square } \\
\text { means }\end{array}$ & $\begin{array}{c}\mathbf{F} \\
\text { value }\end{array}$ & Sig. \\
\hline \multirow{15}{*}{$\begin{array}{l}\text { Religious Commitment among } \\
\text { Irbid University College } \\
\text { Female Students }\end{array}$} & \multirow{3}{*}{ Academic Average } & 0.520 & 2 & 0.260 & \multirow{3}{*}{1.352} & \multirow{3}{*}{0.262} \\
\hline & & 29.418 & 153 & 0.192 & & \\
\hline & & 29.938 & 155 & & & \\
\hline & \multirow{3}{*}{$\begin{array}{l}\text { Father's Degree of } \\
\text { Religiosity }\end{array}$} & 2.033 & 2 & 1.016 & \multirow{3}{*}{5.572} & \multirow{3}{*}{0.005} \\
\hline & & 27.906 & 153 & 0.182 & & \\
\hline & & 29.938 & 155 & & & \\
\hline & \multirow{3}{*}{$\begin{array}{l}\text { Mother's Degree of } \\
\text { Religiosity }\end{array}$} & 0.418 & 2 & 0.209 & \multirow{3}{*}{1.082} & \multirow{3}{*}{0.341} \\
\hline & & 29.521 & 153 & 0.193 & & \\
\hline & & 29.938 & 155 & & & \\
\hline & \multirow{3}{*}{$\begin{array}{c}\text { Relationship } \\
\text { among Parents }\end{array}$} & 2.210 & 2 & 1.105 & \multirow{3}{*}{6.096} & \multirow{3}{*}{0.003} \\
\hline & & 27.729 & 153 & 0.181 & & \\
\hline & & 29.938 & 155 & & & \\
\hline & \multirow{3}{*}{ Income } & 1.039 & 2 & 0.519 & \multirow{3}{*}{2.750} & \multirow{3}{*}{0.067} \\
\hline & & 28.899 & 153 & 0.189 & & \\
\hline & & 29.938 & 155 & & & \\
\hline
\end{tabular}

Table (8) shows the Significance. The table illustrates that is there are significant effect due to the Father's Degree of Religiosity and Relationship among Parents values regarding to the point that the level of significance is less than $(0.05)$. Moreover, there is no significant effect due to rest demographic variables because the level of significance is more than (0.05).

To check the resources of the significant in Father's Degree of Religiosity variable. Scheffe's Test was performed to check for whom the differences belong as shown in the table below:

Table 9. Scheffe's Test to Check the Resources of the Significant for Whom the Differences Belong in Father's Degree of Religiosity Variable

\begin{tabular}{c|c|c|c|c|c}
\hline Dimension & Streams & Mean & $\begin{array}{c}\text { Very } \\
\text { Religious }\end{array}$ & Religious & Irreligious \\
\hline \multirow{2}{*}{$\begin{array}{c}\text { Religious Commitment among Irbid } \\
\text { University College Female Students }\end{array}$} & $\begin{array}{c}\text { Very } \\
\text { Religious }\end{array}$ & 3.99 & & & \\
\cline { 2 - 7 } & Religious & 3.68 & $0.31345^{*}$ & & \\
\cline { 2 - 7 } & Irreligious & 3.62 & 0.37361 & 0.06016 & \\
\hline
\end{tabular}

By using Scheffé's Test, it found that the differences were in Religious commitment among Irbid University College female students for (Very Religious). To check the resources of the significant in Relationship among Parents variable. Scheffé's Test was performed to check for whom the differences belong as shown in the table below: 
Table 10. Scheffé's Test to Check the Resources of the Significant for Whom the Differences Belong in Relationship among Parents Variable

\begin{tabular}{c|c|c|c|c|c}
\hline Dimension & Streams & Mean & $\begin{array}{c}\text { Great Mutual } \\
\text { Understanding }\end{array}$ & $\begin{array}{c}\text { Moderate Mutual } \\
\text { Understanding }\end{array}$ & $\begin{array}{c}\text { Filled with } \\
\text { Problems and } \\
\text { Conflicts }\end{array}$ \\
\hline $\begin{array}{c}\text { Religious } \\
\text { Commitment among } \\
\text { Irbid University } \\
\text { College Female } \\
\text { Students }\end{array}$ & $\begin{array}{c}\text { Great Mutual } \\
\text { Understanding }\end{array}$ & $\begin{array}{c}\text { Moderate Mutual } \\
\text { Understanding }\end{array}$ & 3.86 & & $0.23204 *$ \\
\cline { 2 - 6 } & $\begin{array}{c}\text { Filled with } \\
\text { Problems and } \\
\text { Conflicts }\end{array}$ & 3.55 & 0.31458 & 0.08254 & \\
\hline
\end{tabular}

By using Scheffe's Test, it found that the differences were in favour of all dimensions regarding the criteria (Great Mutual Understanding).

Question (3): What is the level of psychological security for Irbid University College female students?

Means and standard deviation were calculated from the answers that were written by respondents according to the survey fields according to the following table:

Table 11. Descriptive Statistics for Psychological Security Field

\begin{tabular}{c|c|c|c}
\hline $\begin{array}{c}\text { Field } \\
\text { Number }\end{array}$ & Field & Mean & Std. Deviation \\
\hline F1 & Psychological Security & 3.24 & 0.29 \\
\hline
\end{tabular}

As it seen from the above table that the psychological security field achieved mean which reached (3.24) and a standard deviation (0.29).

Question (4): Are there significant differences at the level of significance $(\alpha=0.05)$ for the level of psychological security among Irbid university college female students due to general secondary examination average, parents' religious commitment, family income, and relationship among parents?

In order to answer this question, the researcher used ANOVA analysis to know the differences of the research sample among demographic variables values and the following table shows that:

Table 12. Analysis of Variance ANOVA Values

\begin{tabular}{|c|c|c|c|c|c|c|}
\hline Dimension & $\begin{array}{c}\text { Demographic } \\
\text { Variable }\end{array}$ & $\begin{array}{c}\text { Sum of } \\
\text { Squares }\end{array}$ & $\begin{array}{l}\text { Degree of } \\
\text { Freedom }\end{array}$ & $\begin{array}{c}\text { Square } \\
\text { means }\end{array}$ & $\begin{array}{c}\mathbf{F} \\
\text { value }\end{array}$ & Sig. \\
\hline \multirow{15}{*}{$\begin{array}{l}\text { Psychological Security among } \\
\text { Irbid University College } \\
\text { Female Students }\end{array}$} & \multirow{3}{*}{ Academic Average } & 0.893 & 2 & 0.447 & \multirow{3}{*}{1.395} & \multirow{3}{*}{0.251} \\
\hline & & 48.995 & 153 & 0.320 & & \\
\hline & & 49.888 & 155 & & & \\
\hline & \multirow{3}{*}{$\begin{array}{c}\text { Father's Degree of } \\
\text { Religiosity }\end{array}$} & 3.443 & 2 & 1.722 & \multirow{3}{*}{5.672} & \multirow{3}{*}{0.004} \\
\hline & & 46.445 & 153 & 0.304 & & \\
\hline & & 49.888 & 155 & & & \\
\hline & \multirow{3}{*}{$\begin{array}{c}\text { Mother's Degree of } \\
\text { Religiosity }\end{array}$} & 1.031 & 2 & 0.516 & \multirow{3}{*}{1.615} & \multirow{3}{*}{0.202} \\
\hline & & 48.857 & 153 & 0.319 & & \\
\hline & & 49.888 & 155 & & & \\
\hline & \multirow{3}{*}{$\begin{array}{c}\text { Relationship } \\
\text { among Parents }\end{array}$} & 2.726 & 2 & 1.363 & \multirow{3}{*}{4.421} & \multirow{3}{*}{0.014} \\
\hline & & 47.163 & 153 & 0.308 & & \\
\hline & & 49.888 & 155 & & & \\
\hline & \multirow{3}{*}{ Income } & 1.253 & 2 & 0.626 & \multirow{3}{*}{1.971} & \multirow{3}{*}{0.143} \\
\hline & & 48.636 & 153 & 0.318 & & \\
\hline & & 49.888 & 155 & & & \\
\hline
\end{tabular}


Table (12) shows the Significance. The table illustrates that is there are significant effect due to the Father's Degree of Religiosity and Relationship among Parents values regarding to the point that the level of significance is less than $(0.05)$. In addition, there is no significant effect due to rest demographic variables because the level of significance is more than (0.05).

To check the resources of the significant in Father's Degree of Religiosity variable. Scheffe's Test was performed to check for whom the differences belong as shown in the table below:

Table 13. Scheffé's Test to Check the Resources of the Significant for Whom the Differences Belong in Father's Degree of Religiosity Variable

\begin{tabular}{c|c|c|c|c|c}
\hline \multicolumn{1}{c|}{ Dimension } & Streams & Mean & $\begin{array}{c}\text { Very } \\
\text { Religious }\end{array}$ & Religious & Irreligious \\
\hline \multirow{3}{*}{$\begin{array}{l}\text { Psychological Security among Irbid } \\
\text { University College Female Students }\end{array}$} & $\begin{array}{c}\text { Very } \\
\text { Religious }\end{array}$ & 3.89 & & & \\
\cline { 2 - 6 } & Religious & 3.48 & $0.40313^{*}$ & & \\
\cline { 2 - 7 } & Irreligious & 3.75 & 0.13750 & 0.26563 & \\
\hline
\end{tabular}

By using Scheffe's Test, it found that the differences were in psychological security among Irbid University College female students for (Very Religious).

To check the resources of the significant in Relationship among Parents variable. Scheffés Test was performed to check for whom the differences belong as shown in the table below:

Table 14. Scheffé's Test to Check the Resources of the Significant for Whom the Differences Belong in Relationship among Parents Variable

\begin{tabular}{|c|c|c|c|c|c|}
\hline Dimension & Streams & Mean & $\begin{array}{c}\text { Great Mutual } \\
\text { Understanding }\end{array}$ & $\begin{array}{c}\text { Moderate Mutual } \\
\text { Understanding }\end{array}$ & $\begin{array}{l}\text { Filled with } \\
\text { Problems and } \\
\text { Conflicts } \\
\end{array}$ \\
\hline \multirow{3}{*}{$\begin{array}{c}\text { Psychological Security } \\
\text { among Irbid } \\
\text { University College } \\
\text { Female Students }\end{array}$} & $\begin{array}{c}\text { Great Mutual } \\
\text { Understanding }\end{array}$ & 3.68 & & & \\
\hline & $\begin{array}{l}\text { Moderate Mutual } \\
\text { Understanding }\end{array}$ & 3.43 & $0.25223 *$ & & \\
\hline & $\begin{array}{l}\text { Filled with } \\
\text { Problems and } \\
\text { Conflicts }\end{array}$ & 3.78 & 0.09063 & 0.34286 & \\
\hline
\end{tabular}

By using Scheffe's Test, it found that the differences were in psychological security among Irbid University College female students for the criteria (Great Mutual Understanding).

Question (5): Is there a statistically significant relationship between the level of religious commitment and the level of psychological security among Irbid University College female students?

Pearson's test was used to answer this question to check the relationship between the level of religious commitment and the level of psychological security among Irbid University College female students as shown in the table below:

Table 15. Pearson's Test to Check the Relationship between the Level of Religious Commitment and the Level of Psychological Security among Irbid University College Female Students

\begin{tabular}{c|c|c|c|c}
\hline \multirow{2}{*}{ Dimension } & $\begin{array}{c}\text { Field of } \\
\text { Belief }\end{array}$ & $\begin{array}{c}\text { Field of } \\
\text { Worship }\end{array}$ & $\begin{array}{c}\text { Field of Behaviour } \\
\text { (Treatment) }\end{array}$ \\
\hline \multirow{3}{*}{$\begin{array}{c}\text { Psychological } \\
\text { Security }\end{array}$} & $\begin{array}{c}\text { Pearson's } \\
\text { Correlation }\end{array}$ & 0.083 & 0.003 & $0.189 *$ \\
\cline { 2 - 5 } & Sig. (2-tailed) & 0.302 & 0.966 & 0.018 \\
\cline { 2 - 5 } & $\mathbf{N}$ & 156 & 156 & 156 \\
\hline
\end{tabular}

* Correlation is significant at the 0.05 level (2-tailed).

** Correlation is significant at the 0.01 level (2-tailed).

Table (15) shows the significance. The table illustrates that there is significant effect due to the in the relation between Field of Behaviour (Treatment) and psychological security to the point that the level of significance is less than (0.05).

Moreover, regarding relationship among other dimensions, the table illustrates that there is no significant effect to the 
point that the level of significance is more than $(0.05)$.

\section{Discussion}

\subsection{Discussion of the Results}

Question (1): "What is the level of religious commitment among Irbid University College female students?"

The results indicates that the level of religious commitment among Irbid University College female students is high. The students' answers Moreover, the table also showed that the (Field of Belief) achieved a mean that reached (3.74) with a standard deviation of (0.54), while the (Field of Worship) achieved a mean of (3.88), which is the highest among the three fields, and with a standard deviation of (0.52), whereas the (Field of Behaviour (Treatment)) achieved a mean that reached (3.55), which is the lowest among the three fields, with a standard deviation of (0.57). This could be attributed to the fact that Irbid University College female students have been raised and taught to follow the teachings of Islam by their religious parents, as it is the faith they believe in themselves, and to follow its every teaching, whether it's related to belief, practicing worship rituals (prayers), or follow its provisions in terms of behaviour, and their feelings regarding the closeness of Allah is present among them.

This result is consistent with the result of the study of Miner et al. (2014), which showed that the reassuring and comforting presence of God is present in the world among Christians and Muslims alike, which gives evidence of the closeness of Allah to those who believe in Him and no one else, providing them with a sense of security and great intimacy

Question (2): Are there significant differences at the level of significance $(\alpha=0.05)$ for the level of religious commitment among Irbid University College female students due to academic average, parents' religious commitment, family income, and Relationship among Parents?

It is shown from the results in table (8) that that there isn't a significant impact of the level of religious commitment among Irbid University College female students due to the Academic Average variable, as the level of significance is more than (0.05). This could be due to the fact that females who are religiously committed are more disciplined and committed in their normal, everyday life than females with a low academic average.

This result is contradictory with the result of the study of Carlucci et al. (2015), who highlighted that the main positive role of religious fundamentalism is to encourage life fulfilment and psychological security.

The table has also shown that there is no significant impact of the level of religious commitment among Irbid University College female students due to the Mother's Degree of Religiosity variable, as the level of significance is more than (0.05), whereas tables (8) and (9) showed that there is a significant impact of the level of religious commitment among Irbid University College female students due to Father's Degree of Religiosity variable, where the level of significance is less than (0.05) in all dimensions, and were in favour of ones who were (Very Religious). This could be due to the fact that female students are more affected by the father's level of religiosity than the mother's, as he is the head of the house and the one with the final call. It can also because females are closer to their fathers than their mothers, and so, fathers have more of an impact of them in that sense.

This result is contradictory with the results of the study of Lane (2015), which showed that female participants' religious value transmission is more strongly impacted by their mothers than their fathers.

Table (8) also showed that there isn't a significant impact of the level of religious commitment among Irbid University College female students due to the Income variable as the level of significance is more than (0.05). This can be due to the fact that the wellness of a family in terms of the financial aspect sometimes affects other aspect as well, including religion, where a well-off family that is financially secure can focus on other aspects of life (including religion), while poor families are more concerned with providing for themselves than anything else.

This result, however, is consistent with the results of van Straalen (2015), who showed that Muslims do not seem to draw such a negative attention to excessive consumption or income, as Verses from the Quran show that Muslims even need to focus on spending their money in this life, but in the way of Allah, since it will not be of any use after life.

On the other hand, tables (9) and (10) also showed that there is a significant impact of the level of religious commitment among Irbid University College female students due to the Relationship among Parents variable as the level of significance is less than (0.05) regarding the criteria (Great Mutual Understanding). This can be due to the fact that a good, healthy environment where parents are mutually understanding allows more psychologically secure children to thrive than those who live in an environment where conflicts are constant.

This result is consistent with the results of Goldberg \& Carlson, (2014), which showed that there is some evidence that parents' relationship quality and children's behavioural problems are reciprocally related. 
Question (3): What is the level of psychological security among Irbid University College female students?

It is shown from the results in table (11) that the psychological security field achieved a mean of (3.24), and a standard deviation of (0.29), which is considered moderate. This is due to the fact that most females are religiously committed, and therefore, psychologically secure.

This result is consistent with the result of the study of Rizvi \& Hossain (2017), who found a direct connection between and reaching a state of security and happiness, as well, Muslims seem to be the happiest among the participants, as they claimed their faith is the main source of their feeling of happiness, satisfaction, and comfort.

Question (4): Are there significant differences at the level of significance $(\alpha=0.05)$ for the level of psychological security among Irbid University College female students due to academic average, parents' religious commitment, family income, and Relationship among Parents?

It is shown from the results in table (11) that there are no significant differences for the level of psychological security among Irbid University College female students due to the Academic Average variable, as the level of significance is more than (0.05). This could be due to the fact that more than half the female students are close to each other in terms of the academic average, and are all from Muslim families. Therefore, there are no differences in the female students' psychological security.

The table has also shown that that there aren't any significant differences for the level of psychological security among Irbid University College female students due to the Mother's Degree of Religiosity variable as well, given that the level of significance is more than (0.05), while tables (12) and (13) showed that there are significant differences for the level of psychological security among Irbid University College female students due to the Father's Degree of Religiosity, as the level of significance is less than (0.05), where the differences were in favour of the fields of Belief and Behaviour (Treatment). This could be due to the fact that the degree of religiosity affects the degree of female students' religiosity heavily, as they are the most people that the students come in contact with, and therefore, are more influential than others.

Table (12) also showed that there are no significant differences for the level of psychological security among Irbid University College female students due to the Income variable, as the level of significance is more than (0.05). This can be due to the fact that most female students have the same standard of living (Low), which can be contributed to the difficult economic situation of the country.

On the other hand, Table (14) also showed that there are significant differences for the level of psychological security among Irbid University College female students due to the Relationship among Parents variable, as the level of significance and is in favour of the Psychological Security dimensions regarding the criteria (Very religious). This can be due to the fact that a family with religious parents rarely suffer from problems and conflicts.

Question (5): Is there a statistically significant relationship between the level of religious commitment and the level of psychological security among Irbid University College female students?

It is shown from the results in table (15) that there is a statistically significant relationship between the level of religious commitment and the level of psychological security among Irbid University College female students in the Field of Behaviour (Treatment), as the level of significance is less than (0.05), while it showed there isn't a statistically significant relationship between the level of religious commitment and the level of psychological security among Irbid University College female students in the fields of Belief and Worship. This is because Behaviour is the actual manifestation of faith and worship, as evidenced by many verses and hadeeth in Islam, and that people who believe and always walk the path of Allah feel safe and secure

This is consistent with Sabry \& Vohra's (2013) study, which implied that the religious commitment in Islam refers to the real commitment in behaviour, including mental, psychological, or physical activity individuals do base on Islam teachings.

\subsection{Conclusion}

The importance of the relation between religious commitment and psychological security has been receiving attention from different parties as the days go by, especially in the educational institutions in general and Balqa Applied University in specific. As we have mentioned before, psychological security is one of the basic needs of human beings seek, and without it, many personal and emotional disorders would emerge, which might lead to incidents such as self-harm or suicide, or suffering from mental health issues and emotional imbalance. Thus, numerous study started to emerge and shed light on the matter of religious commitment and its relation to psychological security, while many kindergartens have started to focus on these standards more by applying the necessary adjustments.

The present study was made as an attempt to uncover the relationship between religious commitment and psychological 
security among a sample of Irbid University College students. In light of the results shown in this study, it has been concluded female students' religious commitment was high in terms of beliefs and worship, while in the behaviouristic field the results were intermediate. Moreover, the study has shown statistical differences in terms of father's degree of religiosity in favour of religious ones, and for the Relationship among Parents in favour of having great mutual understanding. In this retrospect, more attention should be paid to the behavioural (treatment) aspect of religion, there should also be a lot of focus on the Islamic values and concepts that enhance young people's psychological security, such as believing in fate, destiny, livelihood, time, the Divine intimacy and the Almighty's compassion toward his righteous servants.

\subsection{Research Limitations and Direction for Further Research}

There were some limitations to this study that must be taken into account; first being the human limitation, where the population of the study was limited only to Female students from Balqa Applied University. The second limitation would be insincerity and conflict when answering the questionnaire by some of the sample members, resulting in these questionnaires being excluded by the researcher and not being included in the final analysis.

The current study recommends going beyond the scope that this study addressed and include both male and female students alike. It also suggested including more universities from across the entire Hashemite Kingdom of Jordan as a follow-up to this research's findings. Further qualitative research would be needed in the future to accurately assert the relation between religious commitment and psychological security among female students at Irbid University College

Further research into the broader relation between religious commitment and psychological security among female students at Irbid University College, as well as new outcomes, whether they are positive or negative, would be highly appreciated by the researchers.

\section{References}

Abeyta, A. A., \& Routledge, C. (2018). The Need for Meaning and Religiosity: An Individual Differences Approach to Assessing Existential Needs and the Relation with Religious Commitment, Beliefs, and Experiences. Personality and Individual Differences, 123, 6-13. https://doi.org/10.1016/j.paid.2017.10.038

Adebayo, G. O., \& Mansikka, J. E. (2018). Human Security and Citizenship in Finnish Religious Education: Rethinking Security within the Human Rights Horizon. Human Rights Review, 1-23. https://doi.org/10.1007/s12142-018-0502-x

Afolabi, O. A., \& Balogun, A. G. (2017). Impacts of Psychological Security, Emotional Intelligence and Self-Efficacy on Undergraduates' Life Satisfaction. Psychological Thought, 10(2), 247-261. https://doi.org/10.5964/psyct.v10i2.226

Agorastos, A., Demiralay, C., \& Huber, C. G. (2014). Influence Of Religious Aspects And Personal Beliefs On Psychological Behavior: Focus On Anxiety Disorders. Psychology Research and Behavior Management, 7, 93-101. https://doi.org/10.2147/PRBM.S43666

Al-Rai Newspaper. (2017, October 12). Mental Illness and Psychological Problems, The Biggest Motive: 104 Cases of Suicide in the Kingdom within 9 Months. Al-Rai Newspaper. Retrieved August 5, 2018, from http://alrai.com/uploads/pdf/2017/10/12/alrai-20171012f.pdf

Amin, M., \& Khah, A. S. (2016). Evaluation of Social and Psychological Factors Affecting the Feeling of Security of Women in Iran. Mediterranean Journal of Social Sciences, 7(3 S2), 123-127.

Bahramian, R., Soltani, I., \& Namdari, K. (2016). The Role of Religious Beliefs in Psychological Empowerment of Orphans of 13-18 Years Old: The Case of Relief Foundation of Isfahan Province. International Journal of Health System and Disaster Management, 4(1), 31-35. https://doi.org/10.4103/2347-9019.175672

Behere, P. B., Das, A., Yadav, R., \& Behere, A. P. (2013). Religion and Mental Health. Indian Journal of Psychiatry, 55(Suppl 2), S187-S194. https://doi.org/10.4103/0019-5545.105526

Bordovskaia, N. V., \& Baeva, I. A. (2015). The Psychological Safety of the Educational Environment and the Psychological Well-Being of Russian Secondary School Pupils and Teachers. Psychology in Russia, 8(1), 86-99.

Bretherton, I. (1992). The origins of attachment theory: John Bowlby and Mary Ainsworth. Developmental psychology, 28(5), p.759. https://doi.org/10.1037/0012-1649.28.5.759

Bu'ud, A., \& Taleb, H. (2016). Aleiltizam Aldyini Waalaqatuh Bibaed Almutaghayirat Alnafsia Walijtimaeia (Altawafuq Alijtimaeii, Taqdir Althat) Eind Eayina Min Talabet Aljama'a [Religious Commitment and Its Relation to Some Psychological and Social Variables (Social Compatibility, Self-Esteem) in a Sample of University Students]. Journal of Humanities and Social Sciences, (27) 143-157.

Carlucci, L., Tommasi, M., Balsamo, M., Furnham, A., \& Saggino, A. (2015). Religious Fundamentalism and 
Psychological Well-Being: An Italian Study. Journal of Psychology and Theology, 43(1), 23-33. https://doi.org/10.1177/009164711504300103

Edling, C., Rydgren, J., \& Bohman, L. (2014). Faith or Social Foci? Happiness, Religion, and Social Networks in Sweden. European Sociological Review, 30(5), 615-626. https://doi.org/10.1093/esr/jcu062

Eisenstein, M. A., \& Clark, A. K. (2014). Political Tolerance, Psychological Security, and Religion: Disaggregating the Mediating Influence of Psychological Security. Politics and Religion, 7(2), 287-317. https://doi.org/10.1017/S1755048314000054

Eisenstein, M. A., \& Clark, A. K. (2018). Gendered Support for Democratic Values? Religion and the Mediating Influence of Psychological Security. Journal of Religion and Society, (20), 1-24.

Fallatah, R. H. M., \& Syed, J. (2018). A Critical Review of Maslow's Hierarchy of Needs. In Employee Motivation in Saudi Arabia (pp. 19-59). Palgrave Macmillan, Cham. https://doi.org/10.1007/978-3-319-67741-5_2

Finne, L. B., Christensen, J. O., \& Knardahl, S. (2014). Psychological and Social Work Factors as Predictors of Mental Distress: A Prospective Study. PloS one, 9(7), 1-12. https://doi.org/10.1371/journal.pone.0102514

Fonagy, P. (2018). Attachment theory and psychoanalysis. Routledge.

Francis, L. J., Ok, Ü., \& Robbins, M. (2017). Religion and Happiness: A Study among University Students in Turkey. Journal of Religion and Health, 56(4), 1335-1347. https://doi.org/10.1007/s10943-016-0189-8

Gazi, A., \& Shemal, S. A. (2017). Psychological Security among the Lecturers in Faculty of Pure Sciences- Ibn al-Haytham University of Baghdad. International Journal of Science and Research, 6(11), 272-285.

Ghamari, T. (2014). Aleiltizam Aldyini Walsiha Alnafsia Fi Aljazair, Tabrir Lilalaqa Al'iijabia Bayn Al'islam Waelm Alnafs [Religious Commitment and Mental Health in Algeria: Justification for the Positive Relationship between Islam and Psychology]. Journal of Islamic Legislation and Ethics - Algeria, 1, 65-86.

Goldberg, J. S., \& Carlson, M. J. (2014). Parents' Relationship Quality and Children's Behavior in Stable Married and Cohabiting Families. Journal of Marriage and Family, 76(4), 762-777. https://doi.org/10.1111/jomf.12120

Golmakani, N., Rezaei, F., \& Mazloum, S. R. (2018). The Relationship of Spiritual Intelligence and Religious Activities with Happiness of Midwives Working in Hospitals and Health Centers. Journal of Midwifery and Reproductive Health, 6(2), 1264-1272.

Gumo, S., Gisege, S. O., Raballah, E., \& Ouma, C. (2012). Communicating African Spirituality through Ecology: Challenges and Prospects for the $21^{\text {st }}$ Century. Religions, 3(2), 523-543. https://doi.org/10.3390/rel3020523

Hiebler-Ragger, M., Falthansl-Scheinecker, J., Birnhuber, G., Fink, A., \& Unterrainer, H. F. (2016). Facets of Spirituality Diminish the Positive Relationship between Insecure Attachment and Mood Pathology in Young Adults. Plos One, 11(6), 1-9. https://doi.org/10.1371/journal.pone.0158069

Kelly, S., \& Noonan, C. (2008). Anxiety and Psychological Security in Offshoring Relationships: The Role and Development of Trust as Emotional Commitment. Journal of Information Technology, 23(40), 232-248. https://doi.org/10.1057/jit.2008.15

Koenig, H. (2018). Religion and Mental Health: Research and Clinical Applications. Academic Press.

Krause, N., Ironson, G., \& Hill, P. (2018). Religious Involvement and Happiness: Assessing the Mediating Role of Compassion and Helping Others. Journal of Social Psychology, 158(2), 256-27 0. https://doi.org/10.1080/00224545.2017.1331992

Kurtz, L. R. (2015). Gods in the Global Village: The World's Religions in Sociological Perspective. California, United States of America: Sage Publications.

Lane, T. (2015). Impact of Parents' Religious Background on Parenting Style and Children's Religiosity in the Orthodox Jewish Community. Unpublished Doctoral Dissertation, State University of New Jersey, New Jersey, United States of America.

Lehmann, D., \& Leighton, C. M. (2018). Jewish-Christian Relations in Historical Perspective. In Irreconcilable Differences? A Learning Resource For Jews And Christians (pp. 15-31). Routledge.

Litwin, H., Schwartz, E., \& Avital, D. (2017). Religiosity and Well-Being among Older Jewish Israelis: Findings from SHARE. Journal of Religion, Spirituality and Aging, 29(2-3), 208-223. https://doi.org/10.1080/15528030.2015.1132491

Madrigal, M. D. (2018). Obsessive-Compulsive Homeland Security: Insights from the Neurobiological Security 
Motivation System. Unpublished Doctoral Dissertation, Naval Postgraduate School, California, United States of America.

Maslow, A., \& Lewis, K. J. (1987). Maslow's hierarchy of needs. Salenger Incorporated, 14, p.987.

McLeod, S., (2007). Maslow's hierarchy of needs. Simply Psychology, 1.

Miner, M., Ghobary, B., Dowson, M., \& Proctor, M. T. (2014). Spiritual attachment in Islam and Christianity: Similarities and differences. Mental Health, Religion \& Culture, 17(1), 79-93. https://doi.org/10.1080/13674676.2012.749452

Perloff, R. M. (2016). An Integrative Terror Management Theory Perspective on Media Effects: A Model and 12 Hypotheses for Research. Studies in Media and Communication, 4(1), 49-62. https://doi.org/10.11114/smc.v4i1.1600

Pope, B., Price, J., \& Lillard, D. R. (2018). The Impact of Religion on Youth Outcomes. The Journal of Business Inquiry, $13(1), 48-60$.

Reinert, D. F., \& Edwards, C. E. (2014). Attachment Theory and Concepts of God: Parent Referencing versus Self-Referencing. SAGE Open, 4(4), 1-9. https://doi.org/10.1177/2158244014560547

Rizvi, M. A. K., \& Hossain, M. Z. (2017). Relationship between Religious Belief and Happiness: A Systematic Literature Review. Journal of Religion and Health, 56(5), 1561-1582. https://doi.org/10.1007/s10943-016-0332-6

Sabry, W. M., \& Vohra, A. (2013). Role of Islam in the Management of Psychiatric Disorders. Indian Journal of Psychiatry, 55(Suppl. 2), 205-214. https://doi.org/10.4103/0019-5545.105534

Sayeed, S. A., \& Prakash, A. (2013). The Islamic Prayer (Salah/Namaaz) and Yoga Togetherness in Mental Health. Indian Journal of Psychiatry, 55(Suppl. 2), 224-230. https://doi.org/10.4103/0019-5545.105537

Shaver, P. (2017). Attachment to Attachment Theory. Voices: Journal of the American Academy of Psychotherapists, p.35.

Shean, J. F. (2016). Spiteful Zeus: The Religious Background to Axial Age Greece. International Journal of Philosophy, (2), 151-170.

Soenke, M., Landau, M. J., \& Greenberg, J. (2013). Sacred Armor: Religion's Role as a Buffer against the Anxieties of Life and the Fear of Death. APA Handbook of Psychology, Religion, and Spirituality, 1, 105-122.

Steger, M. F., Pickering, N. K., Adams, E., Burnett, J., Shin, J. Y., Dik, B. J., \& Stauner, N. (2010). The Quest for Meaning: Religious Affiliation Differences in the Correlates Of Religious Quest and Search for Meaning in Life. Psychology of Religion and Spirituality, 2(4), 206-226. https://doi.org/10.1037/a0019122

Stoyanov, S. (2017). A theory of human motivation. Macat Library.

Tekke, M., Francis, L. J., \& Robbins, M. (2017). Religious Affect and Personal Happiness: A Replication among Sunni Students in Malaysia. Ann Arbor, MI: Michigan Publishing, University of Michigan Library.

Ten Kate, J., De Koster, W., \& Van Der Waal, J. (2017). The Effect of Religiosity on Life Satisfaction in a Secularized Context: Assessing the Relevance of Believing and Belonging. Review of Religious Research, 59(2), 135-155. https://doi.org/10.1007/s13644-016-0282-1

Tracy, J. L., Hart, J., \& Martens, J. P. (2011). Death and Science: The Existential Underpinnings of Belief in Intelligent Design and Discomfort with Evolution. Plos One, 6(3), 1-13. https://doi.org/10.1371/journal.pone.0017349

Van Straalen, J. (2015). The Effect of Income on Religiosity: Comparing Individuals in the Netherlands. Unpublished Bachelor's Thesis, Erasmus University Rotterdam, Rotterdam, Netherlands.

Wagani, R., \& Colucci, E. (2018). Spirituality and wellbeing in the context of a study on suicide prevention in North India. Religions, 9(183), 1-13. https://doi.org/10.3390/re19060183

Woodward, J. (2018). Introduction to attachment theory. In Attachment and human survival (pp. 7-20). Routledge. https://doi.org/10.4324/9780429472039-2

Zotova, O. Y., \& Karapetyan, L. V. (2018). Psychological Security as the Foundation of Personal Psychological Wellbeing (Analytical Review). Psychology in Russia. State of the Art, 11(2), 100-113. https://doi.org/10.11621/pir.2018.0208

Zwoliński, A. (2016). The Christian Understanding of Happiness. The Person and the Challenges. The Journal of Theology, Education, Canon Law and Social Studies Inspired by Pope John Paul II, 6(1), 81-103. https://doi.org/10.15633/pch.1659 


\section{Copyrights}

Copyright for this article is retained by the author(s), with first publication rights granted to the journal.

This is an open-access article distributed under the terms and conditions of the Creative Commons Attribution license (http://creativecommons.org/licenses/by/4.0/). 